\title{
Inhibitory Activity of Bacillus subtilis BCC 6327 Metabolites against Growth of Aflatoxigenic Fungi Isolated from Bird Chili Powder
}

\author{
Rattanaporn Thakaew and Hataichanoke Niamsup
}

\begin{abstract}
The bird chili powder (Capsicum frutescens Linn.) was a source of aflatoxigenic fungus which was identified as Aspergillus flavus. The antagonist Bacillus subtilis BCC 6327 was shown to inhibit the growth and spore germination of the isolated aflatoxigenic fungus from bird chili powder. All the cell free supernatant from 12, 24 and $36 \mathrm{~h}$ of incubation could inhibit the growth and mycelium production with inhibition percentages of $92.1,89.6$ and $90.1 \%$, respectively. Growth of aflatoxigenic fungi was inversely correlated with enzyme productions from $B$. subtilis. Productions of protease, chitinase and $\beta-1,3$-glucanase and the released sugars (total reducing sugar, glucose and $\mathrm{N}$-acetylglucosamine) were enhanced by the dried fungal mycelia. B. subtilis culture filtrates, possessing protease, chitinase and $\beta$-1, 3-glucanase, were capable of hydrolyzing dried mycelia of the isolated aflatoxigenic fungi from bird chili powder.
\end{abstract}

Index Terms-Bird chili powder, Capsicum frutescens., aflatoxigenic fungi, Bacillus subtilis, Aspergillus, protease, chitinase and $\beta-1,3$-glucanase

\section{INTRODUCTION}

Fungi are ubiquitous plant pathogens and major spoilage agents of foods and feedstuffs. The infection of plants by various fungi results in reducing crop yield and quality, leading to significant economic loss. Moreover, the contamination of grains with fungal poisonous secondary metabolites called mycotoxins, causes acute liver damage, liver cirrhosis, induction of tumors and teratogenic effects because mycotoxins are both acutely and chronically toxic to man and animals [1]. One family of mycotoxins, the aflatoxins, is a group of structurally related toxic metabolites produced by Aspergillus flavus and A. parasiticus. Among the major aflatoxins of concern, aflatoxin $\mathrm{B}_{1}\left(\mathrm{AFB}_{1}\right)$ is the most frequently found metabolite in contaminated samples and classified as a human carcinogen [2]. The toxins have been reported in many countries, especially in tropical and

Manuscript received Octorber 15, 2012; revised December 5, 2012. This work was financially supported in part by Postgraduate Education and Research Program in Chemistry, PERCH-CIC and Graduate School, Chiang Mai University

R. Thakaew is with the Graduate School in Biotechnology program, Center of Excellence for Innovation in Chemistry and Department of Chemistry, Faculty of Science, Chiang Mai University, Chiang Mai 50200, Thailand (e-mail: plaboo_nii@hotmail.com).

H. Niamsup is with Center of Excellence for Innovation in Chemistry and Department of Chemistry, Faculty of Science, Chiang Mai University, Chiang Mai 50200, Thailand (e-mail: hataichanoke.n@cmu.ac.th) subtropical regions where conditions of temperature and humidity are favorable for the growth of the molds and the production of the toxin. Unfortunately, aflatoxins are not eliminated completely in food chain. Furthermore, aflatoxins are heat-stable, therefore they are rarely degraded during cooking and processing, making it more difficult to control or eliminate aflatoxins in foods [3].

Chili is grown worldwide as a vegetable and a spice. In Thailand, pungent chili is an economically important crop grown for local consumption, for domestic and international food industry market [4]. Bird chili (Capsicum frutescens Linn.) is one of two chili types widely available in Thailand [5]. Chilies are subject to various pest and disease constraints for optimal production [6] because 1) there is a lack of a proper cleaning process for freshly harvested chili pods, 2) the use of traditional sun drying in the open air, and 3) dried chilies are stored for a long time with moisture contents of approximately $10-12 \%$, leading to microbial contamination and development of mycotoxins [7].

Bacillus subtilis is an aerobic Gram-positive endospore forming microorganism, commonly found in soil and associated water sources. Along with other members of the genus, $B$. subtilis is used extensively in the industrial production of enzymes, biochemicals, antibiotics and insecticides [8]. B. subtilis shows antagonistic activities against several plant pathogens because they have a well-developed secretory system producing diverse secondary metabolites with a wide spectrum of antibiotic activities. Therefore, they are widely used in biocontrol of plant diseases and become very valuable for medical and agricultural applications [9]. The productions of several hydrolytic enzymes that degrade cell walls of pathogenic fungi involved in parasitism of phytopathogenic fungi. Especially chitinases, glucanases and proteases are considered key players in the lysis of cell walls of higher fungi and may be important factors in biological control [10].

The objectives of our study were to isolate aflatoxigenic fungi from chili powder because chilies are susceptible to aflatoxin contamination [11], and to use bacteria for direct biological control.

\section{PROCEDURE}

\section{A. Chili powder samples}

The 3 samples of bird chili powder (Capsicum frutescens Linn.) were collected randomLy from local markets in Chiang Mai, Thailand. The samples were stored at room temperature $\left(25-30^{\circ} \mathrm{C}\right)$ in sterile glass containers after purchase. 


\section{B. Isolation of Fungi from the Dried Chili Powder}

One gram of each chili sample was added into sterile peptone $(1 \% \mathrm{w} / \mathrm{v})$ solution and prepared dilution series up to $10^{-6}$. One $\mathrm{mL}$ of each serial dilution was introduced into five replicate sterile petri dishes and molten potato dextrose agar (PDA) was poured over inoculum. Plates were manually rotated and incubated for one week at $30 \pm 2{ }^{\circ} \mathrm{C}$ [12]. Isolated fungal colonies were transferred to fresh PDA plates under sterile condition and PDA slant for storage. The isolated fungal colonies in fresh PDA plates were incubated for 7 days at $30 \pm 2^{\circ} \mathrm{C}$ and their morphological features were studied and recorded. Slide cultures, freshly prepared slides under sterile condition, culture on PDA with vegetative and reproductive characters were observed under the microscope (40X). The identification of the different forms of fungi was confirmed by comparing with published data or descriptive key [13]. The isolated aflatoxigenic fungi were used in further experiments.

\section{Microorganism}

Bacterial antagonist, Bacillus subtilis BCC 6327 strain was obtained from National Center for Genetic Engineering and Biotechnology (BIOTEC), Thailand. The strain was stored on nutrient agar (NA). The stock culture was grown and maintained at $30{ }^{\circ} \mathrm{C}$ for 3-4 days.

\section{Inhibition of Mycelial Fungal Growth in Broth by Cell Free Supernatant of B. subtilis.}

The preculture of $B$. subtilis strain was inoculated in fresh $300 \mathrm{~mL} \mathrm{NB}$ medium and incubated on a constant temperature shaker $\left(30^{\circ} \mathrm{C}, 160 \mathrm{rpm}\right) .30 \mathrm{~mL}$ culture broth from 3 replicates was collected during $12 \mathrm{~h}, 24 \mathrm{~h}$ and $36 \mathrm{~h}$ of incubation. Cells were removed by centrifugation at 5,520 $\mathrm{xg}$ for $20 \mathrm{~min}$ at $4{ }^{\circ} \mathrm{C}$. The inhibition of mycelia fungal growth by bacterial cell free supernatant was estimated by using the dried mycelial weight [14]. Cell free supernatants were added to autoclaved and pre-cooled potato dextrose broth (PDB) in $100 \mathrm{~mL}$ flasks at concentrations of $25 \% \mathrm{v} / \mathrm{v}$ to a final volume of $30 \mathrm{~mL}$. The control flask was used without cell free culture filtrate. Each treatment flask in 3 replicates was inoculated with $100 \mu \mathrm{l}$ of aflatoxigenic fungi (A. flavus) spore suspension containing $8.62 \times 10^{6}$ spores $/ \mathrm{mL}$ and incubated at $30{ }^{\circ} \mathrm{C}$ in a shaker at $160 \mathrm{rpm}$. Mycelia were harvested after 5 days, filtered, dried, and the mycelial weights were recorded. The percentage of inhibition of mycelial material was calculated from the following equation.

$\%$ Inhibition of mycelial material $=$

(Dried weight of control - Dried weight of treatment) $\times 100$ Dried weight of control

\section{E. The Antagonistic Activity of B. Subtilis against Isolated Aflatoxigenic Fungi on Plate.}

The antifungal activity of $B$. subtilis was determined by dual culture in nutrient agar plate against aflatoxigenic fungi. B. subtilis culture was incubated in nutrient broth at $30{ }^{\circ} \mathrm{C}$, $160 \mathrm{rpm}$ for $54 \mathrm{~h}$. The test plates for dual culture antagonism were prepared by adding $1 \mathrm{~mL}$ spore suspension of $B$. subtilis $\left(10^{8}\right.$ spores $\left./ \mathrm{mL}\right)$ in $10 \mathrm{~mL}$ nutrient agar and shaking by vortex. The spore suspension in nutrient agar was poured into autoclaved petri dish. After solidifying, a mycelial plug of 6 mm diameter from 3 days-old aflatoxigenic fungi was cut and transferred to a nutrient agar plate inoculated with $B$. subtilis. The fungal plug was additionally placed on an uninoculated nutrient agar plate and used as a control. The radii of fungal growth in both the control and dual culture plates were measured at 3 days after incubation. The level of inhibition was defined as the subtraction of the distance of the growth in the dual culture plate ( $r$ in centimeters) from the fungal growth radius ( $r_{0}$ in centimeters) of the control plate, where $\Delta r=r_{0}-r$. And the percentage of inhibition was calculated using the following equation [15],

$$
\% \text { Inhibition of fungal growth }=\frac{r_{0}-r}{r_{0}} \times 100
$$

\section{F. Plate Screening of Hydrolytic Enzymes Produced from B. subtilis}

B. subtilis was screened for its capacity to produce hydrolytic enzymes by agar plate screening. The B. subtilis was grown on nutrient agar supplemented with different substrates for each enzyme production. The different substrates, i.e., $2 \% \mathrm{w} / \mathrm{v}$ soluble starch, $2 \% \mathrm{w} / \mathrm{v}$ colloidal chitin, $1 \%$ w/v casein, $0.2 \%$ w/v Na-Carboxymethyl cellulose and $1 \%$ Tween 20 were used as substrates for assessment of amylase [16], [17], chitinase [18], protease [19], cellulase [20] and lipase, respectively. The $6 \mathrm{~mm}$ plug of B. subtilis was placed at the center of each enzyme screening agar plate and incubated at $30{ }^{\circ} \mathrm{C}$ for 2 or 3 days. After incubation, the colony of $\mathrm{B}$. subtilis which exhibited surrounding clear zone was considered as positive for enzyme production in chitinase and lipase plates. In case of amylase, protease and cellulase, the plates were tested positive for enzyme with reagents $1 \%$ iodine in $2 \%$ potassium iodine, $25 \%$ trichloroacetic acid (TCA) and $25 \%$ congo red, respectively. Each experiment was performed in three replicates.

\section{G. Effect of Dried Mycelia on Production of Lytic Enzymes}

To prepare dried mycelia, $100 \mathrm{~mL}$ of potato dextrose broth was incubated with $6 \mathrm{~mm}$ diameter plug of PDA of actively growing mycelium of isolated $A$. flavus. The inoculated flasks were incubated at $30^{\circ} \mathrm{C}$ for 7 days. The mycelium was collected by filtration through Whatman No.1 filter paper, washed with distilled water and homogenized in distilled water using a laboratory homogenizer. The suspension was centrifuged three times $(5,520 \mathrm{xg}$ for $20 \mathrm{~min})$ after washing with distilled water. The mycelium was stored at $4^{\circ} \mathrm{C}$ until used as C-source [21].

The lytic enzyme production of $B$. subtilis in the in vitro antagonism was tested by culturing the spore suspension of $B$. subtilis $\left(1 \times 10^{8}\right.$ spore $\left./ \mathrm{mL}\right)$ in nutrient broth supplemented with $0.5 \% \mathrm{w} / \mathrm{v}$ dry fungal cell wall from A. flavus. $100 \mathrm{~mL}$ of nutrient broth was incubated with a single colony of $B$. subtilis. The inoculated flasks were incubated at $37^{\circ} \mathrm{C}$ for $20 \mathrm{~h}$ and used as a pre-culture. Spore suspension inocula of B. subtilis $\left(1.0 \times 10^{8} \mathrm{spore} / \mathrm{mL}\right.$ of culture medium) were used and inoculated into duplicated $100 \mathrm{~mL}$ Erlenmeyer flasks containing $20 \mathrm{~mL}$ of nutrient broth supplemented with dried mycelium as the sole carbon source $\left(5 \mathrm{gL}^{-1}\right)$. And the control 
flasks were nutrient broth without dried mycelium. The culture was grown at $37^{\circ} \mathrm{C}$ with rotary shaking at $120 \mathrm{rpm}$ for 5 days. The culture was centrifuged at $4^{\circ} \mathrm{C}$ for $10 \mathrm{~min}$ at 3,840 $\mathrm{xg}$ and clear supernatant was stored at $-20^{\circ} \mathrm{C}$ [21] until used for assaying enzyme activities and determining the amount of released sugar. The cell free supernatant was measured for chitinase, $\beta$-1, 3-glucanase and protease activities by Somogyi's and Nelson's method [18], dinitrosalicylate (DNS) method [22] and Folin reagent, respectively. In addition the supernatant was determined for the release of glucose by using DNS method [22] and measured for $\mathrm{N}$-acetylglucosamine (GlcNAc) reducing sugar using Somogyi's and Nelson's reagent [18]. The amount of total reducing sugars was calculated from summation of the amount of glucose and GlcNAc.

To assess chitinase activity, the assay mixture was prepared composing of $1,000 \mu \mathrm{l}$ of $2 \% \mathrm{w} / \mathrm{v}$ colloidal chitin in $0.1 \mathrm{M}$ potassium phosphate buffer, $\mathrm{pH} 7.0$ as a substrate and $600 \mu \mathrm{l}$ of crude extract. The reaction mixture was incubated for $3 \mathrm{~h}$ at $40^{\circ} \mathrm{C}$ and was stopped by adding $1 \mathrm{~mL}$ of Somogyi's reagent. The mixture reaction was boiled for $10 \mathrm{~min}$ and immediately cooled. $1 \mathrm{~mL}$ of Nelson's reagent was added and incubated at room temperature for 20 minute and $1 \mathrm{~mL}$ of distilled water was added. The mixture was centrifuged at $1,360 \mathrm{xg}, 4^{\circ} \mathrm{C}$ for 20 minute. The supernatant were measured for absorbance at $520 \mathrm{~nm}$. The amount of enzyme required to produce $1 \mu \mathrm{mol}$ of GlcNAc in 1 minute under the experimental condition is defined as 1 unit (U) [18].

$\beta$-1,3-glucanase was assayed by incubating $2.0 \%(\mathrm{w} / \mathrm{v})$ laminarin in $50 \mathrm{mM}$ acetate buffer ( $\mathrm{pH} 4.8)$ with crude extract at $45^{\circ} \mathrm{C}$ for 30 minute. The reaction was stopped by adding 2 $\mathrm{mL}$ of DNS reagent, boiled for $15 \mathrm{~min}$ and immediately cooled. $4 \mathrm{~mL}$ distilled water were added and the absorbance at $540 \mathrm{~nm}$ was measured. One unit of $\beta-1,3$-glucanase is defined as the amount of enzyme capable of producing $1 \mu \mathrm{mol}$ of glucose in 1 minute at $45^{\circ} \mathrm{C}$ [22].

Protease was assayed by incubating $1000 \mu \mathrm{l}$ of $1.5 \%$ (w/v) casein in $0.05 \mathrm{M}$ Na-phosphate buffer ( $\mathrm{pH} 7.0)$ with $500 \mu \mathrm{l}$ crude extract at $40^{\circ} \mathrm{C}$ for 10 minute. The reaction was stopped by adding $2 \mathrm{~mL}$ of $0.4 \mathrm{M}$ trichloracetic acid (TCA) and centrifuge at $1,360 \mathrm{xg}, 4^{\circ} \mathrm{C}$ for 20 minute. $250 \mu \mathrm{l}$ of clear supernatant was added to $1.25 \mathrm{~mL}$ of $0.4 \mathrm{M} \mathrm{Na}_{2} \mathrm{CO}_{3}$ and shaken to mix well. $0.25 \mathrm{~mL}$ of Folin reagent was added and incubated at room temperature for 10 minute. The absorbance was measured at $660 \mathrm{~nm}$. The amount of enzyme required to produce $1 \mu \mathrm{mol}$ of L-tyrosine in one minute, at $40^{\circ} \mathrm{C}$ was defined as 1 unit of proteolytic activity. And the activity of each enzyme was expressed in specific activity (U/mg) per milligram of protein. Protein content was determined by dye binding method of Bradford [23], using bovine serum albumin (BSA) as standard.

The data was statistically analyzed for significance using the Statistix 8.1 program.

\section{RESUlts AND Discussions}

Fungi isolated from serial dilutions mostly appeared as white fungal colonies and, to a lesser extent, black colonies (Fig. 1). Therefore 2 fungal genera identified were A. flavus and A. niger, respectively. The occurrence frequency of $A$. flavus in chili powder showing white colonies (94.62\%) was higher than black colonies of A. niger (5.38\%). After pure cultures were isolated on fresh PDA plates, white colonies turned into green colonies by 4 days of incubation and morphological and reproductive characteristics after slide culture by microscope (40X) were similar to A. flavus (Fig. 2a., 2b). Whereas, black fungal colony was identified as A.niger (Fig. 3a, 3b). The identification was confirmed using a literature [13]. Each Aspergillus species from different chili powders sample showed similar morphological and reproductive characteristics.

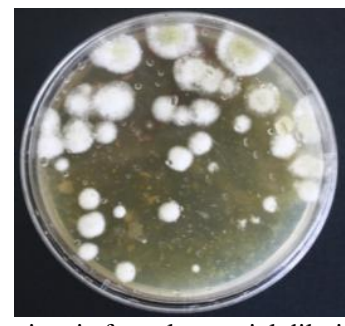

Fig. 1. Aflatoxigenic fungal on serial dilution PDA plate

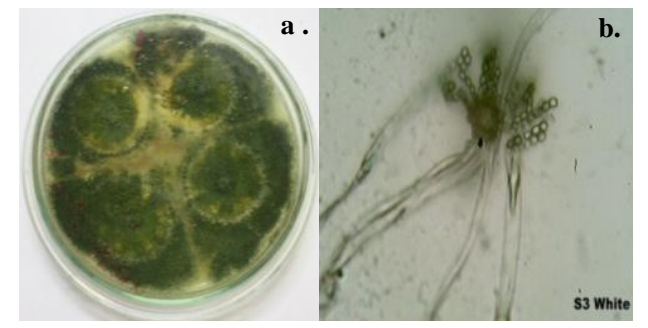

Fig. 2. Aspergillus flavus (a.) 1X, (b.) 40X magnification

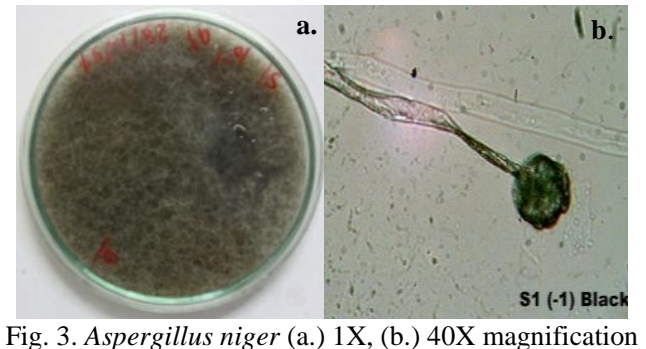

The experiment of the mycelial weight inhibition by $B$. subtilis cell free supernatant was determined after 5 days of incubation. The treatment flasks contained $25 \%(\mathrm{v} / \mathrm{v})$ of cell free supernatant at $12,24,36 \mathrm{~h}$ after inoculation in potato dextrose broth. Mycelia were filtrated, dried and weighed. Compared with the control flask without cell free supernatant, all treatment flasks with $25 \% \mathrm{v} / \mathrm{v}$ cell free supernatant showed a significant reduction in mycelial weight of fungi. The result in table I shows that the highest dried mycelia of fungi was control flask $(0.3171 \mathrm{~g})$ which is significantly higher than treatment flasks with $25 \%$ (v/v) cell free supernatant at 12, 24, and $36 \mathrm{~h}(0.0250,0.0330$, and $0.0315 \mathrm{~g}$ respectively). Mycelial production was reduced with inhibition percentages of $92.1,89.6$ and $90.1 \%$ from cell free supernatants at 12,24 and $36 \mathrm{~h}$, respectively. All the cell free supernatants inhibited growth of aflatoxigenic fungi. Hai [24] reported that $B$. subtilis metabolites inhibited both spore germination and hypha elongation, causing the decrease of fungal development and consequent reduction of the aflatoxin production. 
TABLE I : DRIED WeIGHT OF A. FLAVUS AND PERCENTAGE OF THE FUNGAL MYCELIA INHIBITION BY CELL FREE SUPERNATANTS OF B. SUBTILIS INCUBATED FOR VARIOUS TIME POINTS

\begin{tabular}{clc}
\hline \hline Time of incubation (h) & Dried weight $(\mathrm{g})$ & \%inhibition \\
\hline 0 & $0.3171 \pm 0.0271^{\mathrm{a}}$ & - \\
12 & $0.0250 \pm 0.0015^{\mathrm{b}}$ & 92.1 \\
24 & $0.0330 \pm 0.0015^{\mathrm{b}}$ & 89.6 \\
36 & $0.0315 \pm 0.0028^{\mathrm{b}}$ & 90.1 \\
\hline \hline
\end{tabular}

Mean \pm SD $(n=3)$.

${ }^{\mathrm{a}-\mathrm{b}}$ Means within a column with different superscripts are significantly different $(P<0.05)$.

The dual culture on nutrient agar plate was determined for the fungal growth radius and compared between control (no spore suspension of $B$. subtilis) plates and dual culture plates. A. flavus growth was inhibited by spore suspension of the B. subtilis strain. As the result shown in Table II, a mycelial fungus did not grow on the dual culture plates after 3 days of inoculation and the fungal growth radius was 0.60 $\mathrm{cm}$ in diameter that was the same as the original cut mycelial plug. On control plates uninoculated with spore suspension of $B$. subtilis, the mycelial fungus grew on nutrient agar plates $(2.98 \mathrm{~cm})$ even though grew poorly when compared with potato dextrose agar $(3.99 \mathrm{~cm})$. The level and percentage of inhibition were $3.39 \mathrm{~cm}$ and $85.0 \%$ respectively.

TABLE II : RADII OF FUNGAL GROWTH IN EACH TREATMENT, A. FLAVUS ALONE IN PDA, NA, AND NA CO-CULTURED WITH B. SUBTILIS (DUAL CUlTuRE)

\begin{tabular}{lc}
\hline \hline Treatment & radius of fungal growth $(\mathbf{c m})$ \\
\hline PDA & $3.99 \pm 0.38^{\mathrm{a}}$ \\
NA & $2.98 \pm 0.36^{\mathrm{b}}$ \\
dual culture & $0.60 \pm 0.00^{\mathrm{c}}$ \\
\hline
\end{tabular}

Mean \pm SD (n=3)

${ }^{\mathrm{a}-\mathrm{c}}$ Means with different superscripts are significantly different $(P<0.05)$.

Preliminarily, B. subtilis was screened for its ability to produce hydrolytic enzymes by plate method. The $B$. subtilis was grown on plate agar with different substrates. The different substrates, i.e., soluble starch, colloidal chitin, casein, Na-carboxymethyl cellulose and Tween 20 are used to induce enzyme productions of amylase, chitinase, protease, cellulose and lipase, respectively. Three replicates for each enzyme treatment were incubated at $30^{\circ} \mathrm{C}$ for 2 or 3 days. The colony of $B$. subtilis with surrounding clear zone was considered as positive, after adding specific regents for some enzymes. The result shown in Fig. $4 \mathrm{~b}, 4 \mathrm{c}$, and $4 \mathrm{~d}$ indicated that the $B$. subtilis produced chitinase, protease and cellulase, respectively.

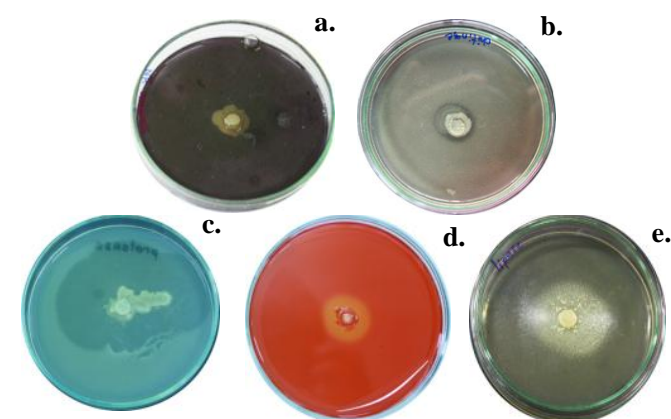

Fig. 4. Plate test for hydrolytic enzyme productions by B. subtilis. Agar plates contained corresponding substrates for (a.) amylase, (b.) chitinase, (c.) protease, (d.) cellulase and (e.) lipase
The lytic enzyme productions by B. subtilis were further investigated if they were induced by the aflatoxigenic cell walls. Significant activities of protease, chitinase and $\beta$-1,3-glucanase were produced by $B$. subtilis both in culture media (nutrient broth) amended with dried mycelium of aflatoxigenic fungi and without dried mycelium (Table III). However, dried mycelia amended in NB caused higher enzyme activity $(0.0907 \mathrm{U} / \mathrm{mg}$ protein) than NB without dried mycelium (0.0657 U/mg protein). Ahmad et al. [25] reported that protease was an important enzyme in pathogenesis which attack the plasma lemma after the degradation of cell wall by proteases along with pectinolytic and cellulolytic enzymes. The chitinase production of $B$. subtilis was also high when grown in NB supplemented with dried mycelia of aflatoxigenic fungi $(0.0185 \mathrm{U} / \mathrm{mg}$ protein) compared with $\mathrm{NB}$ media only ( $0.0092 \mathrm{U} / \mathrm{mg}$ protein). The chitinase produced on this substrate was active against fungi as measured by the release of sugars from their cell walls [16]. The $\beta$-1,3-glucanase production in NB supplemented with dried mycelia (2.2959 U/mg protein) was also significantly higher than NB (1.9831 U/mg protein). Pozo et al. [26] reported that $\beta$-1,3-glucanases are able to partially degrade fungal cell walls by catalyzing the hydrolysis of $\beta-1,3$-glucosidic linkages in $\beta$-D-glucans, which are together with chitin in the major cell wall components of most fungi. Production of extracellular $\beta$-1, 3-glucanase, chitinase and protease increased significantly when $B$. subtilis are grown in media supplemented with dried mycelia of aflatoxigenic fungi. These observations, together with the fact that chitin, $\beta-1,3$ glucan and protein are the main structural components of most fungal cell walls [27], are the basis for the suggestion that hydrolytic enzymes produced by $B$. subtilis play an important role in destruction of plant pathogens.

TABLE III: SPECIFIC ACTIVITIES OF PROTEASE, CHITINASE AND B-1, 3-GLUCANASE FROM $B$. SUBTILIS IN NB WITH AND WITHOUT DRIED MYCELIA

\begin{tabular}{|c|c|c|c|}
\hline \multirow[b]{2}{*}{ Media } & \multicolumn{3}{|c|}{ Specific activity (Unit/mg) } \\
\hline & Protease & Chitinase & $\beta$-1, 3-glucanase \\
\hline $\begin{array}{l}\text { NB and } \\
\text { dried } \\
\text { mycelia }\end{array}$ & $0.0907 \pm 0.0077^{\mathrm{a}}$ & $0.0185 \pm 0.0002^{a}$ & $2.2959 \pm 0.0383^{\mathrm{a}}$ \\
\hline NB & $0.0657 \pm 0.0024^{\mathrm{b}}$ & $0.0092 \pm 0.0000^{\mathrm{b}}$ & $1.9831 \pm 0.0318^{\mathrm{b}}$ \\
\hline
\end{tabular}

Incubation of dried mycelium of the A. flavus with bacterial culture supernatant resulted in a high release of reducing sugars (Fig. 5.). Aflatoxigenic dried mycelium was very sensitive to hydrolysis by $B$. subtilis crude enzyme. More sugar released from $B$. subtilis grown in media supplemented with dried mycelia suggested that this material can act as an inducer of lytic enzyme synthesis. B. subtilis had the potential to produce cell wall degrading enzymes when chitin or isolated fungal cell wall material is present in the growth medium. The secreting hydrolytic enzymes such as protease, $\beta$-1, 3-glucanase and chitinase can penetrate and lyse the cell wall of pathogenic fungi [21]. 


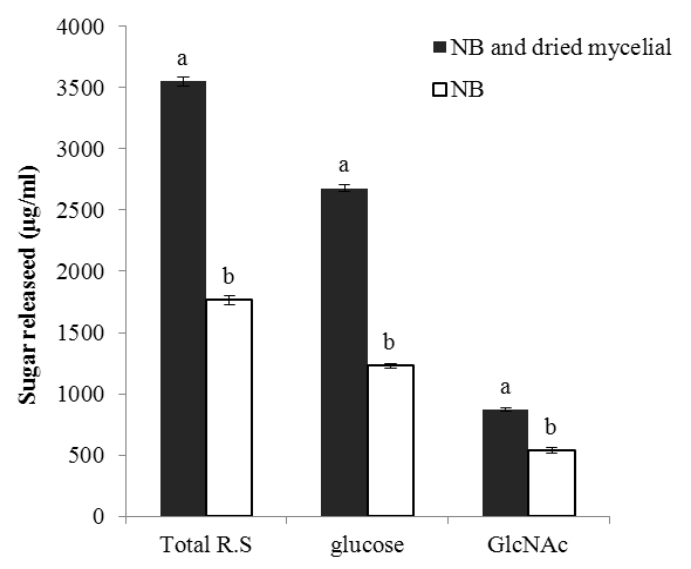

Fig. 5. The amounts of total reducing sugars (R.S.), glucose and $\mathrm{N}$-acetylglucosamine (GlcNAc) released into $B$. subtilis culture supernatant of NB with and without dried mycelia. Different alphabets above the bars of the same sugar type designate significantly different values $(P<0.05)$.

\section{CONCLUSION}

A. flavus was isolated from bird chili powder samples conferring high frequency of occurrence. The mycelial growth of isolated aflatoxigenic fungi (A. flavus) was potentially inhibited by hydrolytic enzymes from cell free culture supernatant of $B$. subtilis. Production of extracellular protease, chitinase and $\beta$-1, 3-glucanase from $B$. subtilis affected to lyse the cell walls of A. flavus, leading to the decrease of fungal development and, consequently reduction of the aflatoxin production. Because of the $B$. subtilis inhibitory activity against the aflatoxigenic fungi, the metabolites may be useful as potential biocontrol agents against aflatoxigenic fungi during food storage.

\section{ACKNOWLEDGMENT}

The authors would like to thank Assoc. Prof. Dr. Nuansri Rakariyatham and Miss Pimpilai Fusawat for their kind provision of the bacterial strain and also thank Miss Dujdao Chunoi for the bird chili powder samples in our study.

\section{REFERENCES}

[1] A. A. Onilude, O. E. Fagade, M. M. Bello, and I. F. Fadahunsi, "Inhibition of aflatoxin-producing aspergilli by lactic acid bacteria isolates from indigenously fermented cereal gruels," African Journal of Biotechnology, vol. 4, no. 12, pp. 1404-1408, Dec 2005.

[2] H. S. Chun, H. J. Kim, H. E. Ok, J. B. Hwang, and D. H. Chung, "Determination of aflatoxin levels in nuts and their products consumed in South Korea," Food Chemistry, vol. 102, pp. 385-391, May 2006.

[3] J. G. Kim, "Anti-aflatoxigenic activity of some bacteria related with Fermentation," in Communicating Current Research and Educational Topics and Trends in Applied Microbiology, A. Méndez-Vilas, Ed. 2007, pp. 322-328.

[4] W. Kraikruan, S. Sukprakarn, O. Mongkolporn, and S. Wasee, "Capsaicin and dihygrocapsaicin contents of Thai chili cultivars," Kasertsart Journal (Natural Science), vol. 42, pp. 611-616, 2008.

[5] W. Wangcharoen, and W. Morasuk, "Antioxidant capacity changes of bird chili (Capsicum frutescens Linn.) during hot air drying," Kasetsart Journal (Natural science), vol. 43, pp. 12-20, 2009.

[6] R. R. M. Paterson, "Aflatoxins contamination in chili samples from Pakistan,” Food Control, vol. 18, pp. 817-820, Apr 2007.

[7] A. D. Duman, "Storage of red chili pepper under hermetically sealed or vacuum conditions for preservation of its quality and prevention of mycotoxin occurrence," Journal of Stored Products Research, vol. 46, no. 3, pp.155-160, Jul 2010.

[8] C. R. Harwood, "Bacillus subtilis and its relatives: molecular biological and industrial workhorses," Trends in Biotechnology, vol. 10, pp. 247-256, Jan 1992.

[9] Y. Liu, Z. Chen, T. B. Ng, J. Zhang, M. Zhou, F. Song, F. Lu, and Y. Liu, "Bacisubin, an antifungal protein with ribonuclease and hemagglutinating activities from Bacillus subtilis strain B-916," Peptides, vol. 28, pp. 553-559, Nov 2006.

[10] C. Leifert, H. Li, S. Chidburee, S. Hampson, S. Workman, D. Sigee, H.A.S. Epton, and A. Harbour, "Antibiotic production and biocontrol activity by Bacillus subtilis CL27 and Bacillus pumilus CL45," Journal of Applied Bacteriology, vol. 78, no. 2, pp. 97-180, Feb 1995.

[11] S. Z. Iqbal, I. A. Bhatti, M. R. Asi, H. N. Bhatti, and M. A. Sheikh, "Aflatoxin contamination in chilies from Punjab Pakistan with reference to climate change," International Journal of Agriculture and Biology, vol. 13, no. 2, pp. 261-265, 2011.

[12] M. Rajasinghe, K. Abeywickrama, and R. Jayasekera, "Aflatoxigenic Aspergillus flavus and aflatoxin formation in selected spices during storage," Tropical Agricultural Research and Extension, vol. 12, no. 1, pp. 1-6, May 2009.

[13] H. L. Barnett, and B. B. Hunter, Illustrated Genera of Imperfect Fungi, 4th ed. New York, USA: Macmillan, 1987, pp. 92-107.

[14] T. Zhang, Z. Q. Shi, L. B. Hu, L. G. Cheng, and F. Wang, "Antifungal compounds from Bacillus subtilis B-FS06 inhibiting the growth of Aspergillus flavus," World Journal Microbiology Biotechnology, vol. 24, pp. 783-788, Sep 2007.

[15] W. M. Yuan, and D. L. Crawford, "Characterization of Streptomyces lydicus WYEC108 as a potential biocontrol agent against fungal root and seed rots," Applied and Environmental Microbiology, vol. 61, pp. 3119-3128, 1995.

[16] R. Gupta, R. K. Saxena, P. Chaturvedi, and J. S. Virdi, "Chitinase production by Streptomyces viridificans: its potential on fungal cell wall lysis," Journal of Applied Bacteriology, vol. 78, no. 4, pp. 378-383, 1995.

[17] G. L. Maria, K. R. Sridhar, and N. S. Raviraja, "Antimicrobial and enzyme activity of mangrove endophytic fungi of southwest coast of India," Journal of Agricultural Technology, vol. 1, pp. 67-80, 2005.

[18] T. Taechowisan, J. F. Peberdy, and S. Lumyong, "Chitinase production by endophytic Streptomyces aureofaciens CMUAc130 and its antagonism against phytopathogenic fungi," Annals of Microbiology, vol. 53, pp. 447-461, 2003.

[19] K. G. Siddalingeshwara, J. Uday, C. H. Huchesh, H. P. Puttaraju, J. Karthic, K. Sudipta, T. Pramod, and T. Vishwanatha, "Screening and characterization of protease from Bacillus sp," International Journal of Applied Biology and Pharmaceutical Technology, vol. 1, no. 2, pp. 575-581, Aug-Oct 2010.

[20] R. C. Kasana, R. Salwan, H. Dhar, S. Dutt, and A. Gulati, "A rapid and easy method for the detection of microbial cellulases on agar plates using gram's iodine," Current Microbiology, vol. 57, no. 5, pp. 503-507, November 2008.

[21] M. H. El-Katatny, W. Somitsch, K. H. Robra, M. S. El-Katatny, and G. M. Gübitz1, "Production of chitinase and $\beta$-1,3-glucanase by Trichoderma harzianum for control of the phytopathogenic fungus Sclerotium rolfsii," Food Technology and Biotechnology, vol. 38, no. 3, pp. 173-180, May 2000.

[22] G. L. Miller, "Use of dinitrosalicylic acid reagent for determination of reducing sugar," Analytical Chemistry, vol. 31, pp. 426-428, 1959.

[23] M. Bradford, "A rapid and sensitive method for the quantitation of microgram quantities of protein utilizing the principle of protein-dye binding," Analytical Chemistry, vol. 72, pp. 248-254, 1976.

[24] N. N. Hai, "Bacillus subtilis possibly used for aflatoxin control," in Proc. of International Workshop on Biotechnology in Agriculture, Nong Lam Univ., Ho Chi Minh city, Vietnam, Oct. 20-21, 2006.

[25] Y. Ahmad, A. Hameed, and A. Ghaffar, "Enzymatic activity of fungal pathogens in corn," Pakistan Journal of Botany, vol. 38, no. 4, pp. 1305-16, 2006.

[26] M. J. Pozo, C. A. Aguilar, E. D. Gaudot, and J. M. Barea, “ $\beta-1$, 3-Glucanase activities in tomato roots inoculated with arbuscular mycorrhizal fungi and/or Phytophthora parasitica and their possible involvement in bioprotection," Plant Science, vol. 141, pp. 149-157, 1999.

[27] J. F. Peberdy, "Fungal Cell Walls," A Review in Biochemistry of Cell Walls and Membranes in Fungi, P. J. Kuhn, A. P. J. Trinci, M. J. Jung, M. W. Goosey, and L. G. Copping, Eds. Berlin: Springer-Verlag, 1990, pp. 5-30. 


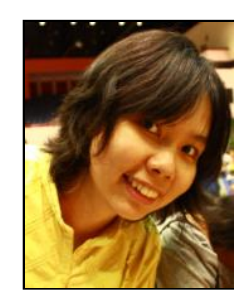

Rattanaporn Thakaew was born on June 12, 1985 in Chiang Mai, Thailand. She received Bachelor degree $\left(1^{\text {st }}\right.$ Class Honor) in product development, Faculty of Agro-industry (2008) from Chiang Mai University. And now, she studies in biotechnology program, Graduate School (2010-present) at Chiang Mai University.

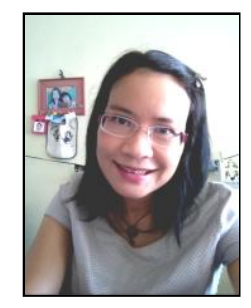

Hataichanoke Niamsup was born in Chiang Mai, Thailand. She received her $1^{\text {st }}$ class honor Bachelor degree in chemistry (1991) from Chiang Mai University and her PhD in biochemistry (1995) from University of Illinois at Urbana-Champaign, USA. She has published 24 papers in national and international journals. She is currently appointed as Assistant Professor at Chiang Mai University. Her research interest is application of molecular biology and biochemistry in agriculture.

Dr. Niamsup is a member of The Science Society of Thailand under the Patronage of His Majesty the King, The Chemical Society of Thailand (CST) under the Patronage of Her Royal Highness Princess Chulabhorn Mahidol, The Thai Society for Biotechnology, The Association of Students supported by the Development and Promotion for Science and Technology talents project (ASDPST). She is also in the editorial board of Chiang Mai Journal of Science. 